\title{
Effects of Dietary Energy Concentration on Reproductive Hormone Secretion and Gene Expression in the Hypothalamus-Pituitary-Gonad Axis in Laying Geese
}

http://dx.doi.org/10.1590/1806-9061-2019-1017

\section{-Author(s)}
Liu Z
Xue J'
(iD) https://orcid.org/0000-0003-3609-8970
(D) https://orcid.org/0000-0003-2463-5249
Luo $Y^{\prime}$ (iD) https://orcid.org/0000-0002-9589-2501
Wang $Q^{\prime}$
Zhong $\mathrm{H}^{\prime}$
Liang $\mathrm{M}^{\prime}$
Wang $\mathrm{C}^{\prime}$
(iD) https://orcid.org/0000-0003-0517-6593
(D) https://orcid.org/0000-0001-6394-4656
(D) https://orcid.org/0000-0001-9794-2819
(iD) https://orcid.org/0000-0002-1490-5746
Chongqing Academy of Animal Sciences, Chongqing, China.

\section{ABSTRACT}

The objective of the study was to investigate the mechanism by which dietary energy concentration regulates laying performance in geese. Eighty 558-day-old female Sichuan White geese were randomly allotted to two dietary treatments, each treatment was fed 1 of 2 experimental diets containing 10.00 (deficient) or $11.80 \mathrm{MJ} / \mathrm{kg}$ metabolizable energy (sufficient) for 30 days. Laying performance, hormone concentration and gene expressions in hypothalamus-pituitary-gonadal axis were examined in geese. Birds fed the sufficient-energy diet had significantly higher average egg weight, daily laying rate, and lower feed to egg ratio than those fed the deficient-energy $(p<0.05)$. The birds fed sufficient-energy diet had higher concentration of serum insulin like growth factor 1 (IGF-1), gonadotropin-releasing hormone $(\mathrm{GnRH})$, follicle-stimulating hormone $(F S H)$ and estradiol $\left(E_{2}\right)$ than those in deficient-energy diet $(p<0.05)$. The mRNA expression levels of $\mathrm{GnRH}$ in the hypothalamus, FSH in the pituitary and $E_{2}$ in the ovary of birds fed sufficient-energy diet were higher than the corresponding counterpart in deficient-energy diet $(p<0.05)$, respectively. In conclusion, the study implied that dietary energy modifies laying possibly through regulating reproductive hormone secretion and gene expression in hypothalamuspituitary-gonad axis in laying geese.

\section{INTRODUCTION}

For poultry, dietary energy concentration is regarded as the most critical nutritive index and energy contributing ingredients are the major cost in feed formula. Many studies have been conducted to examine the effect of dietary energy on growth and egg laying in poultry. For commercial poultry, increasing dietary energy level improves weight gain, and feed utilization efficiency in chickens (Dozier et al. 2006; Ghaffari et al., 2007) and ducks (Fan et al.,2008; Zeng et al.,2015). In breeding poultry, the increase in dietary energy in laying hen improves egg production, egg mass, energy efficiency, yolk and albumen weigh, while it decreases feed intake and feed conversion ratio per kilogram of eggs (Grobas et al., 1999; Pérez-Bonilla et al.,2012). On the other hand, a low-energy diet consumed more feed and produced fewer eggs per day than the hens fed the high-energy diet (Valkonen et al.,2008). Our previous study has shown that low dietary energy decreases average egg weight (up to $7.4 \%$ ), daily laying rate (up to $48.8 \%$ ) when dietary energy decreases from $11.75 \mathrm{MJ} / \mathrm{Kg}$ to $10.01 \mathrm{MJ} / \mathrm{Kg}$, and excessive-low and high dietary energy concentration decreases hatchability of fertile eggs in geese (Luo et al.,2018). However, the mechanism by which dietary energy regulates egg production is poorly understood.

In birds, normal egg laying is dependent on stimulation of the gonadotropic hormones, gonadotropin-releasing hormone $(\mathrm{GnRH})$, follicle stimulating hormone $(F S H)$, as well as oestradiol $\left(E_{2}\right)$. Previous 
studies have confirmed that severely depriving hens of nutrients impairs egg production and the secretion of $\mathrm{E}_{2}$ (Tilbrook et al.,1992), ad libitum feeding increased the number of large pre-ovulatory ovarian follicles, GnRH-I while plasma FSH reduced laying broiler breeder hens (Ciccone et al.,2007), indicating that nutrient provision can regulate egg production and reproductive hormone secretion in birds. Therefore, it was speculated that dietary energy possibly regulates egg production in geese through the manipulation of hormone secretion and relative gene expression. Therefore, the objective of the study was to estimate whether dietary energy manipulates laying performance via affecting hormone secretion and gene expression in laying geese.

\section{MATERIALS AND METHODS}

\section{Ethics statement}

The present research was approved by the animal care and welfare committee of Chongqing Academy of Animal Sciences, China.

\section{Animal and feeding}

Eighty 558-day-old female Sichuan White geese, obtained from the geese breeding centre in Chongqing Academy of Animal Sciences, were randomly allocated to 2 dietary energy treatments with 8 replicate pens of 5 birds per pen. Each treatment was fed 1 of 2 experimental diets containing 10.00MJ metabolizable energy(ME)/kg (deficient) or $11.80 \mathrm{MJ} \mathrm{ME} / \mathrm{kg}$ (sufficient) for 30 days, respectively. Ingredients and nutritional compositions of the deficient-energy diet are shown in Table 1. The sufficient-energy diet was prepared by adding $5 \%$ of soybean oil to deficient-energy diet. $200 \mathrm{~g}$ of experimental feed was provided for each bird per day, and feed given at 8:00 and 15:00, respectively. Experimental birds were kept in plastic-wire-floor pens with dimensions of $250 \times 200 \times 60 \mathrm{~cm}$ in an environmentally controlled geese house, all birds had free access to drinking water, and the light program was $12 \mathrm{~h}$ of light per day.

\section{Sampling and analysis}

Average egg weight, daily laying rate, and feed to egg ratio were calculated throughout the
Table 1 - Ingredients and chemical compositions of the basal diet (\%, as-fed basis).

\begin{tabular}{lclc}
\hline Ingredients & value & Item & Content \\
\hline Corn & 38.50 & Metabolizable energy ${ }^{2}(\mathrm{MJ} / \mathrm{Kg})$ & 10.00 \\
Soybean meal & 21.00 & Crude protein & 18.00 \\
Wheat bran & 27.00 & Calcium & 2.13 \\
Alfalfa power & 6.23 & Total phosphorus & 0.62 \\
CaHPO $_{4}$ & 0.40 & Lysine & 1.02 \\
Limestone $^{\text {Lysine-HCl }}$ & 5.00 & Methionine+ Cysteine & 0.77 \\
Methionine & 0.28 & Threonine & 0.65 \\
Tryptophan & 0.28 & Tryptophan & 0.30 \\
Threonine & 0.09 & Arginine & 1.23 \\
Arginine & 0.02 & & \\
Salt & 0.50 & & \\
Premix & 0.30 & & \\
Total & 0.40 & & \\
\hline
\end{tabular}

'Provided the following per $\mathrm{kg}$ of basal diet: $\mathrm{V}, 20000 \mathrm{IU}, \mathrm{VB}, 4 \mathrm{mg}$, nicotinic acid $65 \mathrm{mg}_{1} \mathrm{VD}_{3} 5000 \mathrm{IU}, \mathrm{V}_{\mathrm{B} 2} 8 \mathrm{mg}$, calcium pantothenate $32.5 \mathrm{mg}, \mathrm{V}_{\mathrm{E}} 33 \mathrm{IU}, \mathrm{V}_{\mathrm{B} 6} 10 \mathrm{mg}$, biotin $0.5 \mathrm{mg}, V_{k 3}^{3} 8 \mathrm{mg}, V_{12} B_{22} 0.034 \mathrm{mg}$, Fe 85mg, Zn 80mg, Cu 8mg, I 1mg, Mn 85mg, Se $4.5 \mathrm{mg}$.

${ }^{2}$ The energy value were calculated according to the ME of feed ingredient in geese (Chen, 2005; Wang, 2012).

experimental period. At 588 days of age, 2 birds per pen were selected, and blood was collected from the wing vein into tube containing $1 \%$ heparin, centrifuged at $1,520 \times \mathrm{g}$ for $10 \mathrm{~min}$ at $4^{\circ} \mathrm{C}$; then the supernatant was collected for determination of $\mathrm{GnRH}$, $\mathrm{FSH}, \mathrm{E}_{2}$ and IGF-1. The hormone was determined using the radio-immunoassay method (Zhao et al.,2017). One bird per pen was slaughtered by manual exsanguination, the hypothalamus, pituitary and ovary were immediately removed, snap-frozen in liquid nitrogen and then stored at $-80^{\circ} \mathrm{C}$ for gene expression analysis. Total RNA was isolated using Trizol reagent (QIAGEN, German). Isolated RNA was quantified by spectrophotometry and its integrity checked using $1 \%$ agarose gel electrophoresis. The expression of three genes (GnRHin hypothalamus, FSH in pituitary, $E_{2}$ in ovary) was measured by quantitative real-time PCR using the ROX Reference Dye II kit (TaKaRa, Dalian, China, Optimal primers for the amplification of these genes (Table 2) were designed using the NCBI website and synthesized by GENEWIZ Biotechnology company. Glyceraldehyde-3-phosphate dehydrogenase (GAPDH) gene was selected as an internal control.

Table 2 - Primer sequences used for qRT-PCR.

\begin{tabular}{lll}
\hline Gene names & GenBank accession & Primer sequences (5'-3') \\
\hline GnRH & EF495207 & Forward:ctgggaccttgctgttttg / Reverse:aggggacttccaaccatcac \\
FSH & EU563911 & Forward:gcttcacaagggatccggta / Reverse:tgaaggagcagtaggatggc \\
E $_{2}$ & XM-013190628 & Forward:gtcaacattctcgcccacat / Reverse:cagggtagacagctcctcag \\
GAPDH & KO1458 & Forward:gtggtgctaagcgtgtca / Reverse:ggctgggataatgttctgg \\
\hline
\end{tabular}


Liu Z, Xue J, Luo Y, Wang Q, Zhong H, Liang $M$, Wang $C$
Effects of Dietary Energy Concentration on Reproductive Hormone Secretion and Gene Expression in the Hypothalamus-Pituitary-Gonad Axis in Laying Geese

Table 4 - Effect of dietary energy concentration on serum hormone in geese during the laying period.

\begin{tabular}{|c|c|c|c|c|}
\hline \multirow[t]{2}{*}{ Items } & \multicolumn{2}{|c|}{ Dietary energy level $(\mathrm{MJ} / \mathrm{kg})$} & \multirow{2}{*}{$\begin{array}{l}\text { Pooled } \\
\text { SEM }\end{array}$} & \multirow[t]{2}{*}{$p$-value } \\
\hline & 10.00 & 11.80 & & \\
\hline $\mathrm{GnRH}(p g / m L)$ & $113.06^{b}$ & $163.86^{a}$ & 11.09 & 0.02 \\
\hline $\mathrm{FSH}(\mathrm{mlU} / \mathrm{mL})$ & $9.62^{b}$ & $12.77^{a}$ & 0.72 & 0.03 \\
\hline $\mathrm{E}_{2}(\mathrm{pg} / \mathrm{mL})$ & $631.22^{b}$ & $1088.17^{a}$ & 111.48 & 0.04 \\
\hline IGF-1(ng/L) & $207.63^{b}$ & $265.63^{a}$ & 11.06 & 0.01 \\
\hline
\end{tabular}

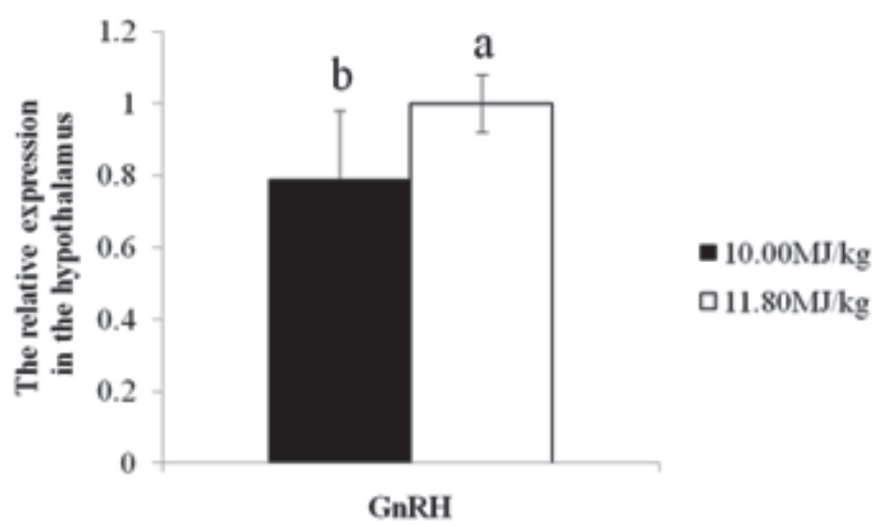

Figure 1 - Effect of dietary energy concentration on GnRH gene mRNA level in the hypothalamus of geese during the laying period.

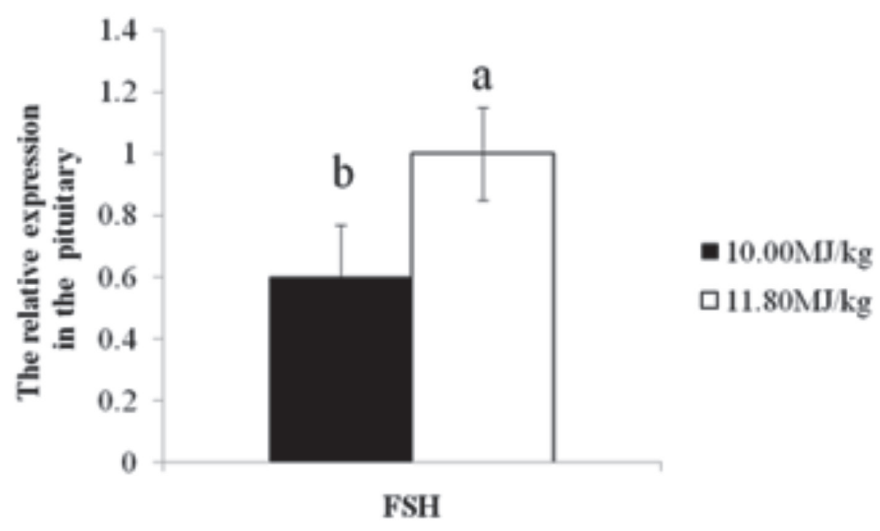

Figure 2 - Effect of dietary energy concentration on FSH gene mRNA level in the pituitary of geese during the laying period.

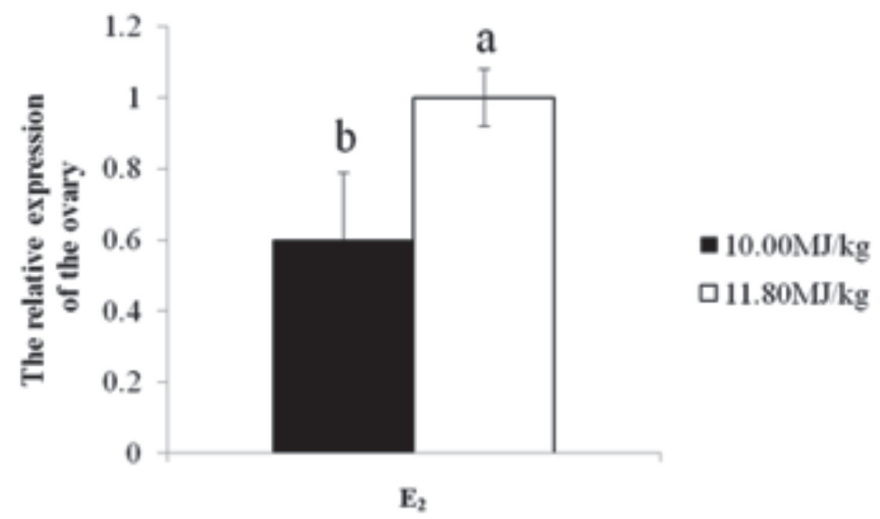

Figure 3 - Effect of dietary energy concentration on E2 gene mRNA levels in the ovary of geese during the laying period.

In avian ovary, IGF-1 is expressed by granulosa and theca cells, stimulatory effect of IGF-1 has 
been reported on chicken granulosa and the caell proliferation (Roberts et al., 1994; Onagbesan \& Peddie, 1995). A variation of energy metabolism through adenosine monophosphate activated protein kinas activation could modulate differently IGF-1-induced progesterone production in F1 and F3/4 granulosa cells (Tosca et al., 2008). In the present study, the increase in the energy concentration resulted in a surge in serum IGF-1 concentration, indicating IGF-1 participated in possibly regulating the dietary energy on egg laying in geese.

GnRHissynthesized in thehypothalamusand released into the hypophyseal portal circulation in a pulsatile fashion, which is a releasing hormone responsible for the release of FSH and LH from the anterior pituitary (Bruni et al., 1977; Rozenboim et al., 1993). Depressed $\mathrm{GnRH}$ secretion is the leading cause for the inhibition of gonadal function and reproductive failure in nutrientrestricted animals (Armstrong \& Britt, 1987; Zhou et al., 2014). In birds, changes in GnRH content and release are correlated with reproductive stages. Hypothalamic $\mathrm{GnRH}$ content in the laying period is significantly higher than in other periods in turkey hen (Rozenboim et al., 1993) and domestic chickens (Dunn et al., 1996). In geese, the concentration of serum GnRH in laying period was higher than that at the nest period (Huang, 2015). GnRH-I mRNA abundance within nucleus commissurae pallii, organum vasculosum lamina terminalis, and nucleus septalis lateralis is greater in egg-laying hens than those in non-photo stimulated and incubating hens (Kang et al., 2006), and a decrease in the expression of the $\mathrm{GnRH}-\mathrm{I}$ gene is a major factor in maintaining depressed $\mathrm{LH}$ secretion in incubating domestic chickens (Dunn et al., 1996). In the present study, a higher serum concentration of GnRH and its mRNA expression in the hypothalamus was observed in high laying-rate geese caused by sufficiency-energy treatment, proving that energy stimulates GnRH secretion and thus improves egg laying.

FSH releases are necessary to induce follicular maturation and ovulation in the hen (Imai \& Nalbandov, 1971), which can facilitate follicle selection and increase the number of follicles (Palmer \& Bahr, 1992). In geese, serum FSH concentrations increased steadily in the pre-laying period, increased rapidly in the laying period, then decreased rapidly in the ceased-laying period (Huang, 2015; Zhao et al., 2017). In the present study, the serum concentration of FSH and its mRNA expression in the pituitary decreased in energetic-restricted birds, implying that deficient energy inhibited FSH secretion and possibly impaired follicle development.
$E_{2}$ plays an important role in follicle development and thus affects egg laying. In hen, $E_{2}$ secretion is enhanced 2-3 weeks before laying and reached its peak in serum in 4-6 hours before ovulation, and $E_{2}$ can promote follicle cells proliferation and inhibited apoptosis (Zhao, 2018). In duck, $E_{2}$ is involved in the regulation of prepubertal follicular development in the ovary of ducks (Ni et al., 2007). A higher concentration of $E_{2}$ was determined in the hypothalamus (Huang, 2015) and serum (Zhao et al., 2017) of the geese in the laying period. In the present study, sufficient energy enhanced serum $E_{2}$ concentration and its mRNA expressions in the ovary, implying that energy regulates laying possibly through manipulating $\mathrm{E}_{2}$ secretion.

\section{CONCLUSION}

Collectively, dietary energy provision could be a critical factor for stimulating laying in geese, dietary energy improves laying performance in geese through a mechanism that promotes reproductive hormone $\left(\mathrm{GnRH}, \mathrm{FSH}\right.$, and $\left.\mathrm{E}_{2}\right)$ secretion and regulates corresponding gene expression in the hypothalamicpituitary-gonadal axis. The findings described here provides valuable insights into the interactions of energy with laying in birds.

\section{ACKNOWLEDGMENTS}

Funding for this study was provided by Fundamental Research Project of Chongqing (Cstc2015jcyjA80034) and China Agriculture Research System (CARS-42-22) and the National Key Research and Development Program (2018YFD0501505).

\section{CONFLICT OF INTEREST}

The authors report no conflicts of interest.

\section{REFERENCE}

Armstrong JD, Britt JH. Nutritionally-induced anestrus in gilts: metabolic and endocrine changes associated with cessation and resumption of estrous cycles. Journal of Animal Science 1987;65(2):508-523.

Bruni JF, Huang HH, Marshall S, Meites J. Effects of single and multiple injections of synthetic GnRH on serum LH, FSH and testosterone in young and old male rats. Biology of Reproduction 1977;17(3):309.

Chen CJ. Comparative study of digestive physiology among chickens, ducks and geese [thesis]. Beijing $(\mathrm{CH})$ : Chinese Academy of Agricultural Sciences; 2005 .

Ciccone NA, Dunn IC, Sharp PJ. Increased food intake stimulates GnRH-I, glycoprotein hormone $\alpha$-subunit and follistatin mRNAs, and ovarian follicular numbers in laying broiler breeder hens. Domestic Animal Endocrinology 2007;33(1):62-76. 
Dunn IC, Beattie KK, Maney D, Sang HM, Talbot RT, Wilson PW. Regulation of chicken gonadotropin-releasing hormone-I mRNA in incubating, nest-deprived and laying bantam hens. Neuroendocrinology 1996;63(6):504-513.

Fan, HP, Xie M, Wang WW, Hou SS, Huang W. Effects of dietary energy on growth performance and carcass quality of white growing pekin ducks from two to six weeks of age. Poultry Science 2008;87(6):1162.

Grobas S, Mendez J, De Blas C, Mateos G. Laying hen productivity as affected by energy, supplemental fat, and linoleic acid concentration of the diet. Poultry Science 1999;78(11):1542-1551.

Huang F. The Related research of hainan dingan goose egg laying, broody law and hormone regulation [dissertation]. Haikou $(\mathrm{CH})$ : Hainan University; 2015.

Imai K, Nalbandov A. Changes in GSH activity of anterior pituitary glands and of blood plasma during the laying cycle of the hen. Endocrinology 1971;88(6):1465-1470.

Kang SW, Thayananuphat A, Rozenboim I, Millam JR, Proudman JA, El Halawani ME. Expression of hypothalamic GnRH-I mRNA in the female turkey at different reproductive states and following photostimulation. General and Comparative Endocrinology 2006;146(2):91-99.

Luo Y, Liu Z, Wang Q, Peng X, Wang Y, Xie M , et al. Effects of dietary energy concentration on growth performance, egg quality and hatching performance in primiparous laying Sichuan white geese. Acta Veterinaria et Zootech-nica Sinica 2018;49(2):439-448.

Ni Y, ZhouY, Lu L, Grossmann R, Zhao R. Developmental changes of FSH-R, LH-R, ER- $\beta$ and GnRH-I expression in the ovary of prepubertal ducks ( Anas platyrhynchos ). Animal Reproduction Science 2007;100(3):318328.

Onagbesan O, Peddie M. Effects of insulin-like growth factor I and interactions with transforming growth factor alpha and $\mathrm{LH}$ on proliferation of chicken granulosa cells and production of progesterone in culture. Journal of Reproduction and Fertility 1995;104(2):259-265.

Palmer SS, Bahr JM. Follicle stimulating hormone increases serum oestradiol-17 beta concentrations, number of growing follicles and yolk deposition in aging hens (Gallus gallus domesticus) with decreased egg production. British Poultry Science 1992;33(2):403-414.

Pérez-Bonilla A, Novoa S, García J, Mohiti-Asli M, Frikha M, Mateos GG. Effects of energy concentration of the diet on productive performance and egg quality of brown egg-laying hens differing in initial body weight. Poultry Science 2012;91(12):3156-3166.
Roberts R, Sharp P, Burt D, Goddard C. Insulin-like growth factor-l in the ovary of the laying hen: gene expression and biological actions on granulosa and thecal cells. General and comparative endocrinology 1994;93(3):327-336.

Rozenboim I, Silsby JL, Tabibzadeh C, Pitts GR, Youngren OM, Halawani ME. Hypothalamic and posterior pituitary content of vasoactive intestinal peptide and gonadotropin-releasing hormones I and II in the turkey hen. Biology of Reproduction 1993;49(3):622-626.

SAS Institute. SAS user's guide: statistics. Version 9.0. Cary; 2003.

Tilbrook AJ, Johnson J, Eason PJ, Walsh JD, Trigg TE, Clarke IJ. Short-term reduction in egg production in laying hens treated with an agonist of GnRH. British Poultry Science 1992;33(3):621-638.

Tosca L, ChabrolleC, Crochet S, Tesseraud S, Dupont J.2008. IGF-1 receptor signaling pathways and effects of AMPK activation on IGF-1-induced progesterone secretion in hen granulosa cells. Domestic Animal Endocrinology 2008;34(2):204-216

Valkonen E, Venäläinen E, Rossow L, Valaja J. Effects of dietary energy content on the performance of Laying hens in furnished and conventional cages. Poultry Science 2008;87(5):844-852.

Wang, XX. Estimation of nutrition value of animal protein and oil in geese [dissertation]. Shandong (CH): Qingdao Agricultural University; 2012.

Wu KL, Zhang YM, Tian YQ, Fu J. Mathematical models for egg production curve of the Sichuan White geese. Acta Veterinaria et Zootech-nica Sinica 1996;27(1):51-54.

Zeng QF, Cherry P, Doster A, Murdoch R, Adeola O, Applegate TJ. Effect of dietary energy and protein content on growth and carcass traits of Pekin ducks. Poultry Science 2015;94(3):384-394.

Zhao D. Effects of estrogen and TGF- $\beta 1$ on development of chicken primordial and growing follicles [dissertation]. Zhejaing $(\mathrm{HC})$ : Zhejaing University; 2012.

Zhao X, Gao G, Wang H, Li Q, Zhang K, Zhong H, et al. Effect of photoperiod on serum hormone concentrations during the annual reproductive cycle in geese. Genetics and Molecular Research 2017;16(1):1-8.

Zhou, D, ZhuoY, Che L, LinY, Fang Z, Wu D. Nutrient restriction induces failure of reproductive function and molecular changes in hypothalamus-pituitary-gonadal axis in postpubertal gilts. Molecular Biology Reports 2014;41(7):4733-4742. 
